\title{
Article \\ Survey of Sugarcane Yellow Leaf Virus in the Canal Point Breeding and Cultivar Development Program
}

\author{
Sushma Sood ${ }^{1, * \mathbb{C}}$, Wayne R. Davidson ${ }^{2}$ and Miguel Baltazar $^{2}$ \\ 1 USDA-ARS, Sugarcane Field Station, Canal Point, FL 33438, USA \\ 2 Florida Sugar Cane League, Clewiston, FL 33440, USA; wayne.davidson@usda.gov (W.R.D.); \\ miguel.baltazar@usda.gov (M.B.) \\ * Correspondence: Sushma.sood@usda.gov
}

check for updates

Citation: Sood, S.; Davidson, W.R.; Baltazar, M. Survey of Sugarcane Yellow Leaf Virus in the Canal Point Breeding and Cultivar Development Program. Agronomy 2021, 11, 1948. https://doi.org/10.3390/ agronomy11101948

Academic Editor: Ryan Whitford

Received: 28 August 2021

Accepted: 27 September 2021

Published: 28 September 2021

Publisher's Note: MDPI stays neutral with regard to jurisdictional claims in published maps and institutional affiliations.

Copyright: (c) 2021 by the authors. Licensee MDPI, Basel, Switzerland. This article is an open access article distributed under the terms and conditions of the Creative Commons Attribution (CC BY) license (https:// creativecommons.org/licenses/by/ $4.0 /)$.

\begin{abstract}
Sugarcane yellow leaf virus (SCYLV), a Polerovirus in the family Luteoviridea, causes yellow leaf disease (YLD). Yield losses from YLD have been reported from several countries in both symptomatic and asymptomatic sugarcane cultivars. The breeding nursery at Canal Point (CP) in 2016 and primary and secondary seed increases in the CP cultivar development program at grower's farm from 2015 to 2019 were surveyed for SCYLV infection by the tissue-blot immunoassay using polyclonal antibodies raised against SCYLV. More than $32 \%$ of varieties in the CP breeding nursery were infected with SCYLV in 2016. The SCYLV data of primary and secondary seedcane increases from 2015 to 2019 showed that out of 54 varieties screened at different locations, 12 had no SCYLV-positive plants, 24 had less than $5 \%, 5$ had $6 \%$ to $12 \%$, and 13 had $20 \%$ to $75 \%$ of the plants infected with SCYLV. The SCYLV screenings in varieties in the primary and secondary seed increase plantings provide growers an opportunity to acquire virus-free clean seedcane by apical meristem propagation to minimize the spread of the SCYLV and avoid yield losses.
\end{abstract}

Keywords: sugarcane yellow leaf virus (SCYLV); germplasm; tissue-blot immunoassay; survey

\section{Introduction}

Sugarcane is an important crop, contributing to $80 \%$ of the sugar consumed in the world. It had a positive annual economic impact of more than $\$ 647.5$ million in Florida in 2018 [1]. Sugarcane grows on approximately 161,874.3 ha in Florida [2] and provides approximately $20 \%$ of the total sugar consumed in the USA. Sugarcane is also used for biofuel production [3,4] in several countries. More than 100 pathogens including bacteria, fungi, phytoplasmas, and viruses impact sugarcane production. One of the viral diseases, yellow leaf disease (YLD) caused by sugarcane yellow leaf virus (SCYLV) a Polerovirus [5] in the family Luteoviridea [6], is a major threat to sugarcane production worldwide [7]. YLD exhibit various symptoms such as mild to severe yellowing of the midribs, smaller leaves with clustering (fan-like shape) at the crown region of the plant along with the shortened internodes, necrosis of leaves from tip to the base of leaves [8]. A majority of the SCYLV-infected varieties in the Canal Point breeding and cultivar development program (CP program) and commercial cultivars in Florida are asymptomatic $[9,10]$. Many visual symptoms that resembled YLD symptoms may be caused by other biotic and abiotic stresses or plant senescence [11,12], making the survey of YLD difficult. The detection of SCYLV is, therefore, dependent on immunological assays, reverse transcription (RT)polymerase chain reaction (PCR), quantitative (q) RT-PCR and other molecular detection methods. For this study, we used the tissue-blot immunoassay for SCYLV detection in more than five thousand samples every year. It has been reported that low SCYLV titer in some older leaves may fall below the sensitivity threshold of the immunoassay [12]. Another study reported that all samples from leaves number 1 to 3 showed a reliable positive reaction [13] by TBIA. We used the top visible dewlap leaf for SCYLV detection by TBIA. Comstock et al. [14] reported that RT-PCR and TBIA were sensitive in SCYLV detection. 
The SCYLV has a single-stranded positive-sense RNA genome $[15,16]$ and eight different genotypes-BRA (Brazil), CHN1 and CHN3 (China), CUB (Cuba), HAW (Hawaii), IND (India), PER (Peru), and REU (Reunion Island) - that have been reported from different countries based on the phylogenetic analysis of partial and/or full-length genome sequences [15-18]. The two genotypes, BRA and CHN1, are present in sugarcane in Florida [9]. The SCYLV is reported to alter the metabolism and transport of sucrose and photosynthesis $[19,20]$. These alterations limit plant development and cause losses in sugarcane productivity [21,22]. In the United States of America, 11-14\% yield losses were reported from Florida and Louisiana [10,23]. However, Lockhart and Cronje [24] reported yield losses of $15 \%$ and up to $50 \%$ from the United States. Growing resistance varieties is the most efficient, economic, and environmentally friendly strategy to control any disease but due to lack of efficient inoculation technique and absence of visual symptoms [25], breeding for YLD resistance is a challenge. Several studies to identify loci associated with YLD resistance using biparental progenies [26,27] or genome-wide association mapping [28-30] could be helpful in breeding for SCYLV-resistant varieties. SCYLV is transmitted and spread semi-persistently by aphids, mainly Melanaphis sacchari, Rhopalosiphum maidis, and R. rufiabdominalis [31], depending on cultivar susceptibility and weather conditions [32,33]. However, a recent study showed that the transmission of SCYLV by aphid M. sacchari is not efficient in Florida [34]. Other aphids including yellow sugarcane aphid (Sipha flava) and Ceratovacuna lanigera have been reported to transmit SCYLV from infected to healthy plants $[35,36]$. In the field, SCYLV spread readily by the use of infected seedcane (setts) for plantings [33]. The spread of SCYLV can be reduced by the use of virus-free seedcane produced by apical meristem culture [37-40]. The CP program has been developing disease-resistant sugarcane cultivars with $\mathrm{CP}$ prefixes for Florida under a cooperative agreement between the USDA-ARS, the University of Florida, and the Florida Sugar Cane League, Inc. (Clewiston, FL, USA) since 1960. CP cultivars are grown in more than $95 \%$ of sugarcane acreage in Florida and in many Central American countries. The CP program uses germplasm collection from different countries and breeding programs as well as many promising $\mathrm{CP}$ varieties and cultivars to breed and develop sugarcane cultivars. The varieties are not bred or selected for SCYLV resistance in the CP program due to the lack of a mechanical inoculation protocol to screen a large number of varieties; however, the varieties in its germplasm were screened every five years and in seedcane increase plantings every year. The $\mathrm{CP}$ program has six stages of breeding and selection: crossing, seedlings, stages I, II, III, and IV [41]. It takes at least eight years to release a cultivar from the time a cross is made [42]. The potential varieties to be released for commercial production are advanced to primary seedcane increase followed by secondary seedcane increase. The objectives of this study were to evaluate the prevalence of SCYLV infection in the germplasm of the CP program and SCYLV status of the varieties in the primary and secondary seedcane increases to provide breeder and growers the SCYLV status of the varieties used in crossing and commercial production.

\section{Materials and Methods}

\subsection{Collection of Samples}

The top visible dewlap leaf was randomly collected for each variety from five, thirty, and fifty plants, respectively, in the $\mathrm{CP}$ breeding nursery, primary and secondary seedcane increase fields. The leaf samples were collected from plant cane. Approximately $80 \%$ (1195 varieties) of the CP breeding nursery (Table 1) was surveyed for SCYLV infection in 2016. The CP breeding nursery was planted in February 2015 and each plot was $\sim 3.7 \mathrm{~m}$ in length with an $1.8 \mathrm{~m}$ alley. The varieties in the seed increases (primary and secondary) of the CP program were also tested annually for the SCYLV infection from 2015 to 2019. Each plot in the primary increase consisted of 3 rows $\sim 135 \mathrm{~m}$ in length and each plot in the secondary increase consisted of 2 rows $\sim 777 \mathrm{~m}$ in length. The primary and secondary increases are planted at different locations throughout South Florida. The varieties for primary and secondary increases in seedcane on muck soil were planted at seven commercial growers' 
farms (Area 4 of US Sugar Corporation (A4, 26 $51^{\prime} 34.7^{\prime \prime} \mathrm{N} 80^{\circ} 36^{\prime} 23.3^{\prime \prime} \mathrm{W}$ ), A. Duda \& Sons, Inc. (Belle Glade, FL, USA) (DU, 26 $35.93^{\prime} \mathrm{N}, 80^{\circ} 37.81^{\prime} \mathrm{W}$ ), Eastgate Farms, Inc. (Pahokee, FL, USA) (EG, $26^{\circ} 47.67^{\prime} \mathrm{N}, 80^{\circ} 39.97^{\prime} \mathrm{W}$ ), Knight Management, Inc. (Sixmile Bend, FL, USA) (KN, $26^{\circ} 38.53^{\prime} \mathrm{N}, 80^{\circ} 27.21^{\prime} \mathrm{W}$ ), Okeelanta Corporation (South Bay, FL, USA) $\left(\mathrm{OK}, 26^{\circ} 34.35^{\prime} \mathrm{N}, 80^{\circ} 49.72^{\prime} \mathrm{W}\right.$ ), Sugar Farms Cooperative North-Osceola Region (Pahokee, FL, USA) (SF, $26^{\circ} 50.53^{\prime} \mathrm{N}, 80^{\circ} 31.93^{\prime} \mathrm{W}$ ), and Wedgworth Farms, Inc. (Belle Glade, FL, USA) (WD, $26^{\circ} 40.73^{\prime} \mathrm{N}, 80^{\circ} 34.37^{\prime} \mathrm{W}$ ) and on sand soils in four commercial growers' farms (Hilliard Brothers of Florida Ltd. (Montura, FL, USA) (HI, $26^{\circ} 42.14^{\prime} \mathrm{N}, 81^{\circ} 2.31^{\prime} \mathrm{W}$ ), Pahokee Produce Inc. (Westlake, FL, USA) (PP, 26 $6^{\circ} 47.26^{\prime} \mathrm{N}, 80^{\circ} 25.09^{\prime} \mathrm{W}$ ), Perry Farms/Lykes Bros. (Moore Haven, FL, USA) (PF, $26^{\circ} 45.7^{\prime} \mathrm{N}, 80^{\circ} 23.7^{\prime} \mathrm{W}$ ), and Townsite (Clewiston, FL, USA) (TS, $26^{\circ} 44.37^{\prime} \mathrm{N}, 80^{\circ} 58.95^{\prime} \mathrm{W}$ ) in November each year. Since 2016, primary and secondary seed increase fields on sand soil were planted at Shawnee farm (Shawnee, FL, USA) (SH, $26^{\circ} 46.59^{\prime} \mathrm{N}, 80^{\circ} 58.02^{\prime} \mathrm{W}$ ) (Figure 1). The primary and secondary seed increase trials started at the SH location in 2016 and the PF location the following year. In 2015, nine varieties in primary increase and five varieties in the secondary increase were surveyed. In 2016, the primary and secondary increases had eight varieties in each trial but only two varieties were on muck soil. In 2017, 2018, and 2019, the primary and secondary increase trials together, respectively, consisted of 17,9 , and 11 varieties.

Table 1. Number of varieties in Canal Point breeding nursery in 2016.

\begin{tabular}{cccc}
\hline \multicolumn{2}{c}{ Tested for SCYLV } & \multicolumn{2}{c}{ Not Tested for SCYLV } \\
\hline${ }^{1}$ CL & 143 & CL & 0 \\
CP & 311 & CP & 37 \\
CPCL & 159 & CPCL & 11 \\
Ho & 43 & Ho & 64 \\
HoCP & 59 & HoCP & 49 \\
L & L & 28 \\
Q & 14 & Q & 7 \\
TCP & 23 & TCP & 9 \\
US & 87 & US & 60 \\
Other & 246 & Other &
\end{tabular}

${ }^{1}$ Prefixes: Clewiston (CL); Canal Point (CP); Canal Point $\times$ Clewiston (CPCL); Houma (Ho); Houma $\times$ Canal Point $($ HoCP); Louisiana (L); Queensland (Q); Texas $\times$ Canal Point (TCP); Varieties from Canal Point wide crosses (US).

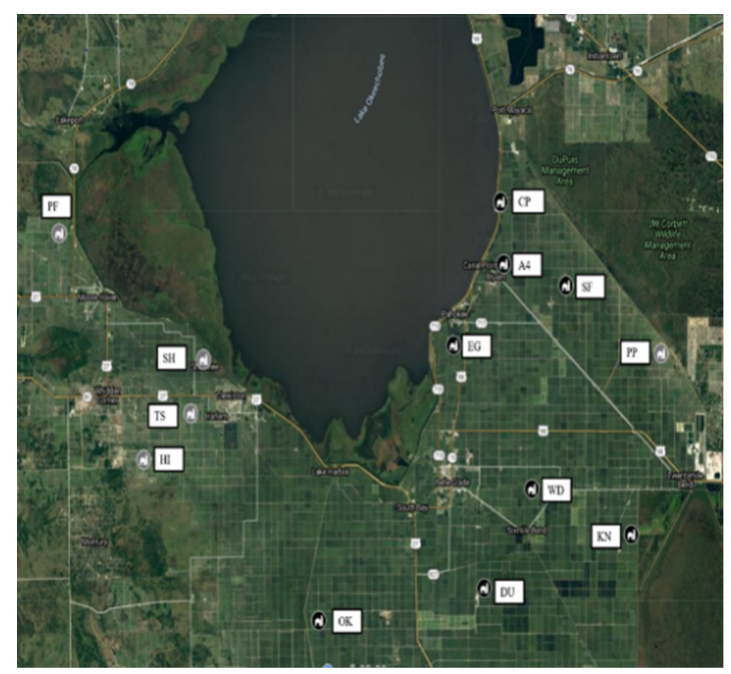

Figure 1. Sugarcane seedcane primary and secondary increase fields located at growers' farm during 2015 to 2019. Muck soil fields were located at Area 4 (A4), Duda (DU), Eastgate (EG), Knight (KN), Okeelanta (OK), South Florida (SF), and Wedgeworth (WD). Sand soil fields were located at Hilliard brothers (HI), Pahokee Produce (PP), Perry Farm (PF), Shawnee Farm (SH), and Townsite (TS). 


\subsection{Tissue-Blot Immunoassay (TBIA)}

Tissue blots were made from the midribs of the first-dewlap leaves that were transversely cut with a razor blade and immediately pressed onto a $0.45 \mu \mathrm{m}$ nitrocellulose membrane (Biorad Laboratories, Hercules, CA, USA). The tissue-blot membranes (membranes) were kept at $4{ }^{\circ} \mathrm{C}$ until processed as described by Schenk et al. [43]. All the steps (1 to 9) described below were performed on a shaker at $75 \mathrm{rpm}$. (1). Membranes were blocked in $2 \%$ non-fat dry milk ( $2 \%$ milk) dissolved in a TBIA buffer $(100 \mathrm{mM}$ Tris- $\mathrm{HCl}$, $\mathrm{pH} 7.5$, and $150 \mathrm{mM} \mathrm{NaCl}$ ) for $1 \mathrm{~h}$ at room temperature. (2). Membranes were rinsed once in a TBIA buffer for $1 \mathrm{~min}$. (3). Membranes were placed into a SCYLV polyclonal antibody IgG solution (Dr. B. E. L. Lockhart, University of Minnesota, St Paul, MN, USA) diluted $(1: 8000)$ in $1 \%$ dry milk in TBIA buffer for $3 \mathrm{~h}$ at room temperature. (4). Membranes were rinsed three times in TBIA buffer for 5 min each. (5). Membranes were incubated in alkaline phosphatase-conjugated goat anti-rabbit IgG (Sigma-Aldrich, St. Louise, MI, USA) diluted (1:2000) in $1 \%$ dry milk in TBIA buffer) for $3 \mathrm{~h}$ at room temperature. (6). Membranes were rinsed twice in TBIA buffer for 15 min each. (7). Membranes were incubated for $30 \mathrm{~min}$ in the dark in a substrate solution made of substrate buffer $(300 \mathrm{mM}$ Tris base, $\mathrm{pH} 9.1 ; 6 \% w / v$ solution of Naphthol in dimethylformamide); Fast Blue BB salts $(0.1 \% w / v)$ and $0.1 \mathrm{M} \mathrm{MgCl}_{2}(0.5 \% v / v)$. (8). The membrane was soaked in $20 \%$ household bleach for $5 \mathrm{~min}$. (9). Finally, membranes were rinsed in distilled water and dried on a paper towel. The membranes were inspected for blue color development in the phloem tissue (Positive reaction to SCYLV, Figure 2 ) with a stereomicroscope $(100 \times)$. Positive reactions were determined by comparing them with resistant controls (CP 57-603). A plant was considered infected by SCYLV when at least one vascular bundle of one leaf showed a positive reaction.

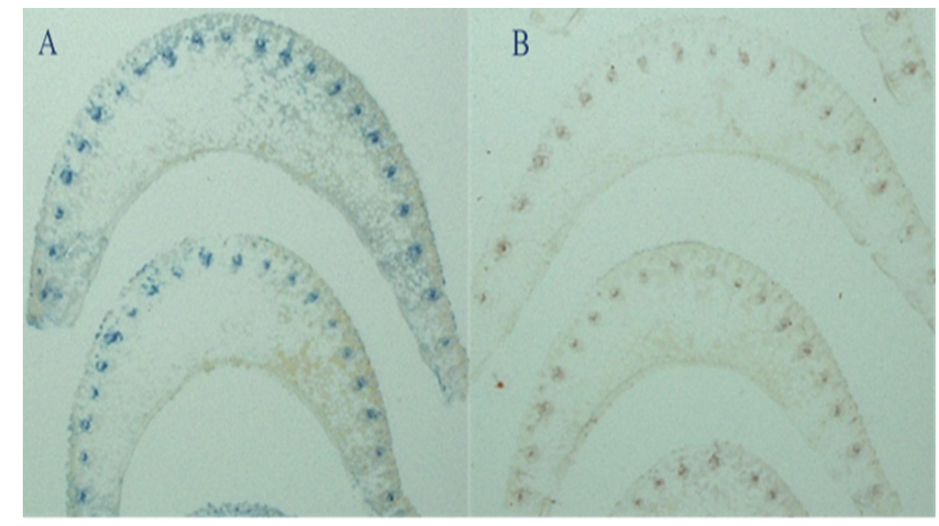

Figure 2. Tissue-blot immunoassay of midrib of top visible dewlap leaves. (A) Infected leaves; (B) healthy leaves. The blue dots are stained phloem cells where the virus lives.

\subsection{Data Collection and Analysis}

Percent SCYLV incidence was calculated to determine the SCYLV infection in large and small seed increase plantings and the $\mathrm{CP}$ breeding nursery.

Percent incidence in CP breeding nursery $=$ Number of varieties with SCYLV-positive results with the same prefix/Total number of varieties tested with the same prefix $\times 100$

Percent incidence in primary and secondary seedcane increase trials $=$ Number of leaves with SCYLV/Total number of leaves tested $\times 100$

Analyses of variance were performed using SAS/GLIMMIX in SAS 9.4 (SAS Institute, 2011) to determine statistically significant differences among clones, locations, and years. Varieties were clustered based on their percent incidence to SCYLV by K-mean clustering analysis using RStudio. 


\section{Results}

\subsection{Percent Incidence in the CP Breeding Nursery}

The survey of varieties in the CP breeding nursey conducted in 2016 showed that $37.23 \%$ of the tested varieties were infected with the SCYLV. The percent SCYLV incidence in the varieties from different breeding programs ranged from $13.95 \%$ to $62.68 \%$ (Table 2). The highest percentage (62.68\%) of CL varieties were infected with SCYLV followed by L (57.14\%). The CP breeding nursery had varieties with a series as early as 27 (1927) and as late as 11 (2011). Some varieties could be older than 1927 (data not shown).

Table 2. Percent incidence of sugarcane yellow leaf virus in the Canal Point breeding nursery.

\begin{tabular}{ccc}
\hline Prefixes & Breeding Program & Percent Infected Varieties \\
\hline CL & Clewiston & 62.68 \\
CP & Canal Point & 46.18 \\
CPCL & Canal Point Clewiston & 27.22 \\
Ho & Houma & 13.95 \\
HoCP & Houma Canal Point & 27.11 \\
L & Louisiana & 57.14 \\
Q & Queensland & 30.43 \\
TCP & Texas Canal Point & 35.63 \\
US & Canal Point wide crosses & 27.07 \\
Others & Several programs & 29.41 \\
\hline
\end{tabular}

\subsection{Percent Incidence in the Primary and Secondary Seedcane Increase Trials}

The data collected from the primary and secondary seedcane increase plantings from 2015 to 2019 showed that out of 55 varieties screened at different locations, 12 were free of SCYLV, 24 had less than 5\% SCYLV incidence, 5 had approximately $15 \%$, and 13 had $20 \%$ to $75 \%$ of the plants infected with SCYLV (Table 3). The SCYLV incidence was not significantly $(p<0.05)$ different between varieties with 0 to $2.4 \%$ SCYLV incidence (Table 3$)$. The percentages of disease incidence ranged from $1.09 \%$ to $90.92 \%$ in the CP 06 series in 2015. In addition, no variety was SCYLV negative. In contrast, The CP 07 series had only two varieties with 1.30 and $9.67 \%$ of SCYLV incidence (Table 3). The two siblings CP 09-1132 and CP 09-1137 from a cross between SCYLV-free female CPCL 97-0393 and SCYLV-infected male CP $00-2188$ had $0 \%$ and $30 \%$ plants infected, respectively (Table 3). In contrast, another two sets of siblings had the same level of SCYLV infection (Table 3). One set CP 09-1807 and CP 09-1822 originated from a cross between two SCYLV-free parents (CP 01-2459 and CPCL 02-8021), and another set of siblings CP 09-1385 and CP 09-1390 originated from SCYLV-free female (CP 01-2459) and SCYLV-infected male (CP 00-2188). Most parents (Table 3) of the varieties in the primary and secondary increase were SCYLV infected (data not shown). Some varieties in the primary and/or secondary increases had SCYLV-infected plants at several locations, while some varieties had SCYLV-infected plants only at one location (Supplementary Table S1). The varieties in the primary and secondary increases from 2015 to 2019 were divided into three clusters by K-mean analysis (Figure 3). The red circle represents cluster 1 , blue circle cluster 2 , and purple circle cluster 3 . The resistant varieties were grouped in cluster 1, somewhat resistant in cluster 2, and susceptible varieties in cluster 3 (Figure 3). 
Table 3. Mean percent incidence of sugarcane yellow leaf virus in primary and secondary seedcane increases from 2015 to 2019.

\begin{tabular}{|c|c|c|c|}
\hline Variety & Female & Male & Percent Incidence * \\
\hline СР07-1313 & ТСР00-4519 & CP84-1198 & $0.00^{\mathrm{a}}$ \\
\hline СР09-1132 & CPCL97-393 & СР00-2188 & $0.00^{\mathrm{a}}$ \\
\hline СР09-1236 & CP84-1198 & CL89-5189 & $0.00^{\mathrm{a}}$ \\
\hline СР09-1512 & CPCL00-4027 & СР01-2390 & $0.00^{\mathrm{a}}$ \\
\hline СР09-1894 & CPCL00-4027 & СР01-2459 & $0.00^{\mathrm{a}}$ \\
\hline СР09-2002 & СР01-2390 & Poly06-32 & $0.00^{\mathrm{a}}$ \\
\hline СР09-2392 & СР 01-2390 & POLY 07-04 & $0.00^{\mathrm{a}}$ \\
\hline CP10-1132 & СР00-1074 & Mix07G & $0.00^{\mathrm{a}}$ \\
\hline CP10-1938 & СР01-2390 & Mix07 S & $0.00^{\mathrm{a}}$ \\
\hline CP11-1314 & СР05-1451 & Mix08-B & $0.00^{\mathrm{a}}$ \\
\hline CP11-1325 & CP01-2390 & Poly08-19 & $0.00^{\mathrm{a}}$ \\
\hline CP12-2441 & НоСР05-923 & НоСР96-540 & $0.00^{\mathrm{a}}$ \\
\hline CP10-2195 & СР01-2390 & POLY07-04 & $0.30^{\mathrm{a}}$ \\
\hline СР08-1110 & СР01-2459 & СР00-2188 & $0.40^{\mathrm{a}}$ \\
\hline CP10-1734 & СР98-1029 & Mix07 Q & $0.56^{\mathrm{a}}$ \\
\hline CP10-2002 & СР98-1029 & Mix07 U & $0.56^{\mathrm{a}}$ \\
\hline СР09-1807 & СР01-2459 & CL02-8021 & $0.67^{\mathrm{a}}$ \\
\hline CP10-1208 & СР01-2390 & ТСР98-4454 & $0.67^{\mathrm{a}}$ \\
\hline CP10-1716 & СР00-2180 & Mix07 Q & $0.67^{\mathrm{a}}$ \\
\hline CP10-2149 & СР98-1029 & US02-0099 & $0.89^{\mathrm{a}}$ \\
\hline СР08-2022 & СР02-2103 & СР80-1743 & $1.00^{\mathrm{a}}$ \\
\hline СР09-2067 & СР88-1762 & Poly06-35 & $1.09^{\mathrm{a}}$ \\
\hline СР06-2964 & СР94-2095 & СР97-1387 & $1.11^{\mathrm{a}}$ \\
\hline CP10-1189 & СР03-1912 & Mix07H & $1.11^{\mathrm{a}}$ \\
\hline СР09-1390 & СР01-2459 & СР00-2188 & $1.13^{\mathrm{a}}$ \\
\hline СР06-2042 & СР96-1252 & 01P04 & $1.20^{\mathrm{a}}$ \\
\hline СР07-2137 & СР01-2390 & СР84-1198 & $1.33^{\mathrm{a}}$ \\
\hline СР09-1822 & СР01-2459 & CL02-8021 & $2.00^{\mathrm{a}}$ \\
\hline СР09-1952 & СР01-2390 & Poly06-30 & $2.00^{\mathrm{a}}$ \\
\hline CP10-2413 & СР98-1029 & ТСР00-4518 & $2.48^{\mathrm{a}}$ \\
\hline CP10-1313 & СР98-1029 & Mix07 I & $2.78^{a b}$ \\
\hline СР09-1430 & CPCL00-6756 & СР01-2390 & $2.92^{a b}$ \\
\hline СР09-1385 & СР01-2459 & СР00-2188 & $3.89 \mathrm{ab}$ \\
\hline CP10-1620 & СР00-1100 & СР05-1740 & $4.58^{a b}$ \\
\hline СР09-1906 & CPCL96-4974 & СР01-2459 & $4.67^{\mathrm{ab}}$ \\
\hline CP10-1134 & СР00-1074 & Mix07G & $4.67^{\mathrm{ab}}$ \\
\hline CP11-2423 & CPCL06-3272 & НоСР96-540 & $6.00^{a b}$ \\
\hline CP10-1619 & unknown & unknown & $7.25^{a b c}$ \\
\hline CP12-2213 & CPCL05-1102 & СР80-1743 & $7.50 \mathrm{abc}$ \\
\hline СР07-2320 & СР02-2065 & СР96-1865 & $11.00^{a b c}$ \\
\hline CP12-1417 & СР02-2065 & Poly09-16 & $12.07^{a b c}$ \\
\hline CP10-1177 & СР03-1912 & Mix07H & $20.78^{a b c}$ \\
\hline CP12-2035 & СР99-1896 & Poly09-26 & $26.73 \mathrm{bcd}$ \\
\hline CP11-2248 & СР06-2664 & Poly09-24 & 29.57 cdef \\
\hline СР09-1137 & CPCL97-393 & СР00-2188 & 30.00 cdef \\
\hline CP11-1956 & СР03-2188 & СР01-2459 & $39.45^{\text {defg }}$ \\
\hline CP11-1640 & СР01-2390 & Poly08-19 & 40.00 defg \\
\hline CP12-2479 & unknown & unknown & 40.42 defg \\
\hline СР09-1266 & СР02-1143 & СР92-1167 & $43.33^{\text {defg }}$ \\
\hline СР09-1098 & СР02-1143 & СР03-1939 & 47.14 efgh \\
\hline CP10-1296 & СР98-1029 & Mix07 I & 51.13 efgh \\
\hline СР09-1874 & СР03-1026 & CPCL00-6756 & $70.83 \mathrm{hi}$ \\
\hline CP10-1717 & СР00-2180 & Mix07 Q & $75.00^{\mathrm{i}}$ \\
\hline
\end{tabular}

${ }^{*}$ Mean of SCYLV data from all the locations, years, stages and including leaves without SCYLV. Percent incidence values with different lower case letters are significantly different $(p<0.05)$. 


\section{CLUSPLOT( SCYLV)}

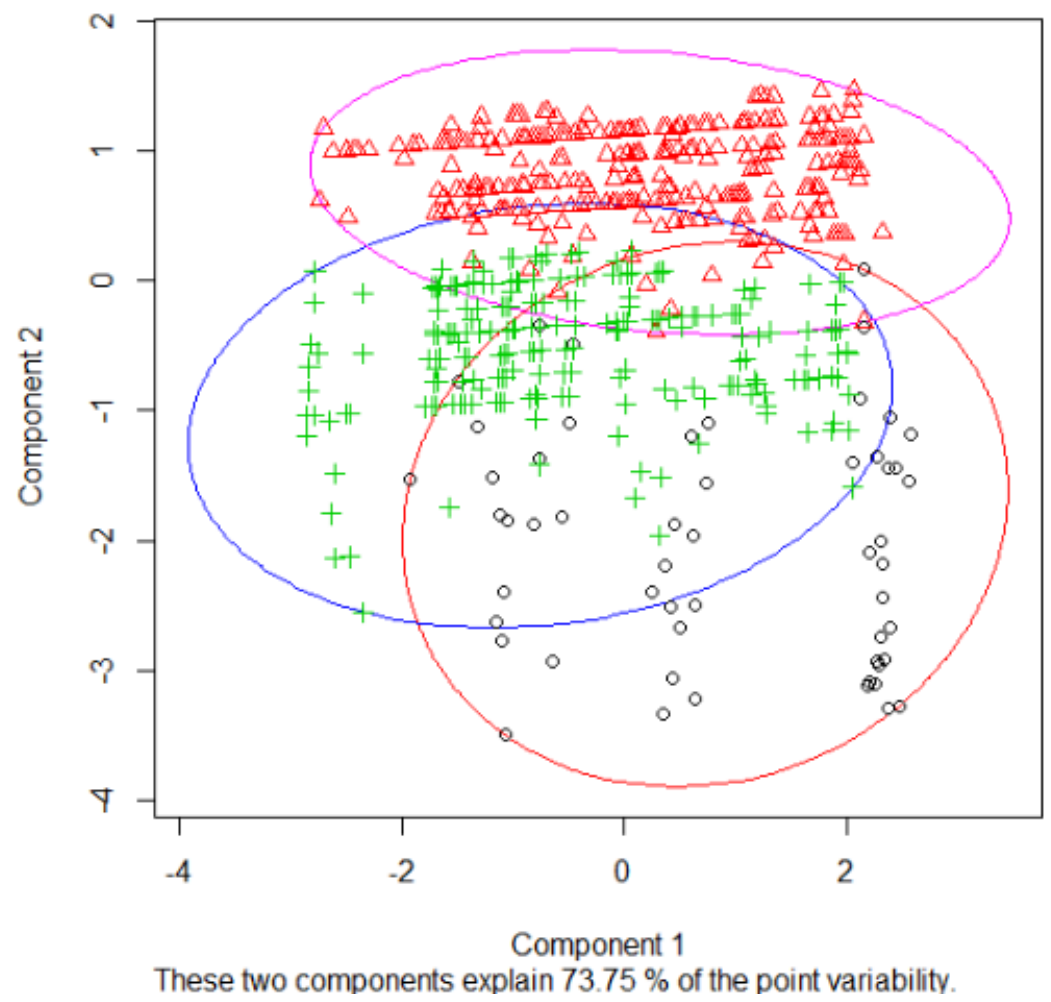

Figure 3. Varieties were divided into three clusters based on percent incidence of SCYLV analyzed by k-means clustering. The red circle represents cluster 1 , blue circle cluster 2 , and purple circle cluster 3 . $\mathrm{o}$, varieties in the cluster $1,+$, varieties in the cluster 2 and $\Delta$,varieties in the cluster 3.

The varieties planted in the primary and secondary increase trials in 2015 had the lowest SCYLV incidence followed by the varieties planted in 2018 but the SCYLV incidence in 2015 and 2018 was not significantly $(p<0.05)$ different. Similarly, no significant difference in disease incidence was detected between 2016 and 2017. The percent SCYLV incidence was the highest in 2019 and was significantly $(p<0.05)$ higher than all three years (Figure 4$)$.

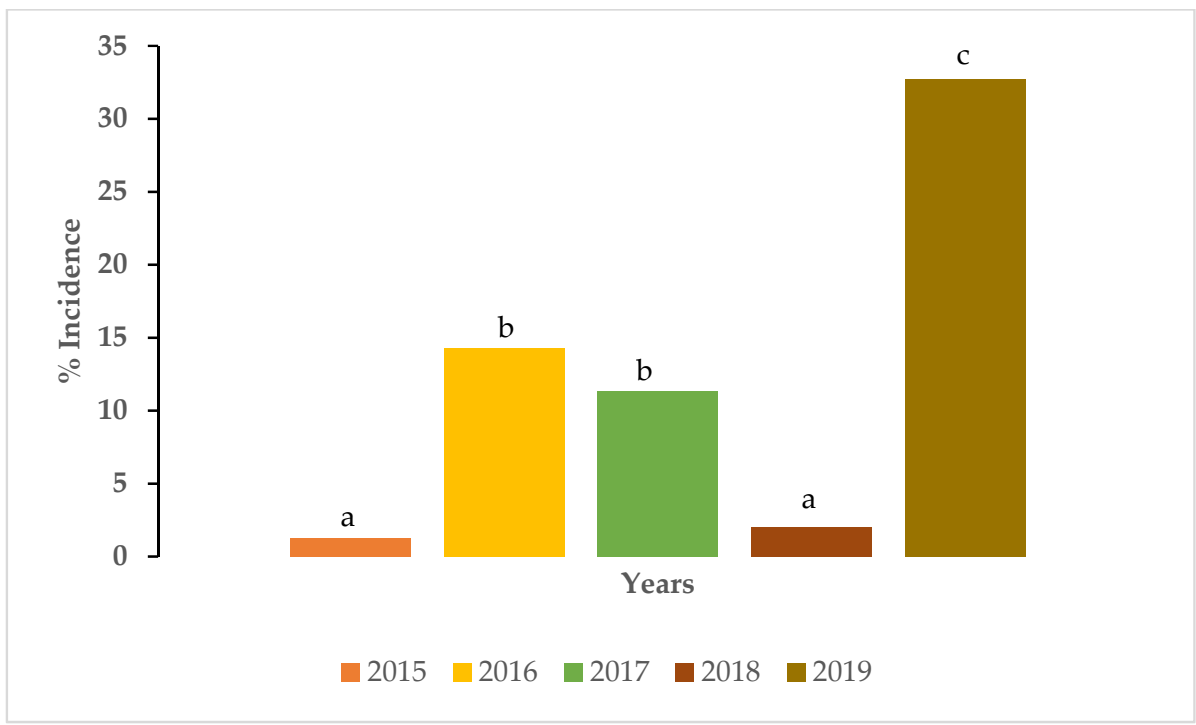

Figure 4. Percent incidence of sugarcane yellow leaf virus in varieties in the primary and secondary increase trials in different years. Percent incidence values with different lower case letters are significantly different $(p<0.05)$. 
The SCYLV incidence was different at each location. In general, Pahokee produce had the lowest incidence of SCYLV, and Duda had the highest incidence of SCYLV. The SCYLV incidence at Pahokee produce was not significantly $(p<0.05)$ different from the other four sand locations (HI, PF, SH, and TS) and at one muck location (SF). In addition, the SCYLV incidence at the Wedgeworth location was not significantly $(p<0.05)$ different from the SCYLV incidence at Shawnee and South Florida locations. Similarly, SCYLV incidence was significantly $(p<0.05)$ similar at Area4, East gate, Knight, and Okeelanta locations. The SCYLV incidence at DUDA was significantly $(p<0.05)$ higher than all the sand locations and SF muck location (Figure 5).

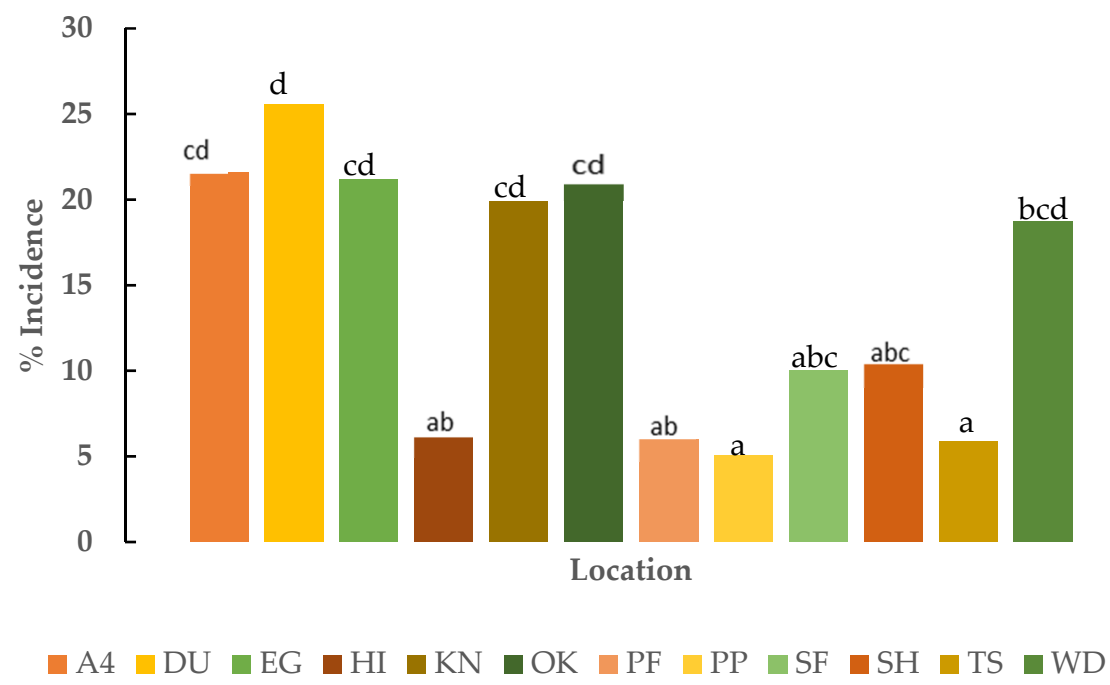

Figure 5. Percent incidence of sugarcane yellow leaf virus in varieties in the primary and secondary increase trials at different locations. Locations are Area 4 (A4), Duda (DU), Eastgate (EG), Hilliard (HI), Knight (KN), Okeelanta (OK), Pahokee Produce (PP), Perry Farm (PF), Shawnee (SH), South Florida (SF), Townsite (TS), and Wedgeworth (WD). Percent incidence values with different lower case letters are significantly different $(p<0.05)$.

The effect of variety, location, and year had a very high significant $(p<0.0001)$ effect on SCYLV incidence. The interaction of the variety $\times$ year and interaction of all three components had a significant $(p<0.0001)$ effect on SCYLV incidence (Table 4$)$. The interaction between variety and location had no significant $(p=0.1575)$ effect on SCYLV incidence, whereas the interaction between location and year had some significant $(p=0.015)$ effect on SCYLV incidence (Table 4).

Table 4. F statistics for variety, location, year and their interaction effects on sugarcane yellow leaf virus incidence.

\begin{tabular}{cccc}
\hline Trait & DF & F & $p$ \\
\hline Variety (V) & 54 & 6.52 & $<0.0001$ \\
Location (L) & 11 & 2.86 & $<0.0001$ \\
Year (Y) & 4 & 10.3 & $<0.0001$ \\
$\mathrm{~V} \times \mathrm{L}$ & 368 & 1.23 & 0.158 \\
$\mathrm{~L} \times \mathrm{Y}$ & 42 & 1.58 & 0.015 \\
$\mathrm{~V} \times \mathrm{Y}$ & 108 & 5.51 & $<0.0001$ \\
$\mathrm{~V} \times \mathrm{L} \times \mathrm{Y}$ & 421 & 181.29 & $<0.0001$ \\
\hline
\end{tabular}

\section{Discussion}

We surveyed 1195 varieties in the CP breeding nursery in 2016 and 54 varieties in the primary and secondary seedcane increase plantings at six and four locations, respectively, on muck and sand soils over 2015 to 2019. The results of this survey showed that the SCYLV is widespread in Florida. Similar findings were reported in other studies $[14,44]$. 
A metagenomics study of Saccharum germplasm from Miami, Florida detected SCYLV in more than $80 \%$ of samples [14]. A total of $37.25 \%$ of the 1195 varieties surveyed in the CP breeding nursery were infected with the SCYLV. A higher SCYLV incidence in the germplasm in Florida was reported in 2003 [44]. The current germplasm at the CP is different than in 2003. Twenty-one percent of the varieties (Table 1) tested were US varieties and only $27 \%$ of the US varieties were susceptible to SCYLV (Table 2). In addition, the Florida sugarcane industry has been using SCYLV-free seeds for commercial production for approximately two decades; the lower SCYLV incidence in the breeding nursery could be due to lower SCYLV titer available for the infection of the newer varieties. It has been reported recently that the main vector ( $M$. sacchari) of SCYLV was not able to transmit SCYLV efficiently in Florida [34]. More than 40\% of CP varieties in the breeding nursery were infected with SCYLV (Table 2); which was also lower than the earlier report [44]. The $\mathrm{CP}$ breeding nursery includes varieties released for the commercial production and other promising varieties from the advance stages of the CP cultivar development program each year and, therefore, the varieties that were positive in the 2003 report [44] contributed to a smaller ratio of varieties in 2016 in the CP breeding nursery. The varieties in CP breeding nurseries are used as parents for crossing to develop cultivars for the Florida sugarcane industry. To develop disease-resistant cultivars, identification of the source of resistance is the prerequisite. Several breeding programs worldwide survey their germplasm for yellow leaf disease symptoms on a disease rating scale developed for their breeding program. SCYLV resilient genotypes were recognized, and disease-resistant progenies were developed successfully $[12,45]$. Most of the varieties in Florida are asymptomatic and, therefore, we used TBIA to identify SCYLV-negative varieties in the local collection of the germplasm and the primary and secondary seed increases. TBIA was shown to be as sensitive as RT-PCR [14], only three cultivars out of 71 cultivars that were determined positive to SCYLV by RT-PCR were negative by TBIA, similarly, five cultivars that were negative to SCYLV by RT-PCR were positive by DAS-ELISA [14]. Another study compared the detection of SCYLV by RT-PCR and viral metagenomic-based screening and found that $80 \%$ of the samples had the same results by both tests but $20 \%$ of the samples were tested positive by either one or other, not by both [9]. When highly reliable detection of SCYLV is critical then using at least two detection methods have been recommended [46] To test more than 5000 samples every year, the TBIA is a suitable diagnostic technique to survey varieties in our breeding program. We often randomly perform a qRT-PCR test on varieties that had a negative TBIA reaction to confirm the specificity of SCYLV antibodies to the SCYLV genotypes present in Florida. The selection of sugarcane parents for crossing is a critical decision for breeders so the knowledge of the SCYLV infection status of varieties in the CP germplasm is useful information for future crossing efforts to develop SCYLV resistant/tolerant varieties. Lack of SCYLV-resistant germplasm (Table 2), as well as a mechanical inoculation technique, make it difficult to develop and select SCYLVresistant cultivars in Florida and, therefore, the use of clean seedcane for plantings is the best alternative to grow SCYLV-free sugarcane. The survey of SCYLV infection in the varieties in the primary and secondary seedcane increases (Table 3) provides the status of SCYLV in the varieties released to sugarcane growers for commercial production. This allows growers to acquire SCYLV-free seedcane. The varieties negative to SCYLV by TBIA can be further tested by RT-PCR and/or RT-qPCR so they can be used immediately without micropropagation to save time and resources. There were 25 varieties with SCYLV incidence up to $2 \%$, these varieties can be used by the growers who do not use SCYLV clean seedcane but they should avoid repropagation of infected seeds. Schenck and Lehrer [33] found that within a year 0 to $90 \%$ of virus-free plants were re-infected in commercial plots. An increase in SCYLV incidence from 30\% to 55\% within 3 years in the CP sugarcane cultivar development program was reported by Comstock and Miller [44]. The aphid vector M. sacchari and other aphids may disseminate the virus among the plants [33,47], but the speed of infection propagation from plant to plant is only a few meters per year [48]. A recent study showed that the M. sacchari is not efficient to transmit SCYLV in Florida [34]. 
However, this aphid has been reported to be sufficiently fast to infect susceptible varieties within a few years in Hawaii [48]. Several reports [47,49,50] found that yellow leaf spread by aphids depends on cultivar susceptibility, epidemiological conditions, and aphid predator populations. This could be a reason for variation in SCYLV incidence at the different locations and years. The varieties with higher than $2 \%$ SCYLV incidence should be cleaned by the micropropagation of the meristem tip. SCYLV-free plants had $44 \%$ more stalks, contributing to a $35 \%$ increase in sugar yield than SCYLV-infected plants [7].

\section{Conclusions}

In conclusion, this survey of SCYLV incidence in the primary and secondary seedcane increases allowed us to identify very promising SCYLV-resistant varieties. These varieties could be tested by RT-qPCR or another detection method for SCYLV infection. These resistant varieties will be a good resource for SCYLV resistance for the $\mathrm{CP}$ program because these varieties have already been selected for good agronomic and yield traits.

Supplementary Materials: The following are available online at https:/ /www.mdpi.com/article/ 10.3390/agronomy11101948/s1, Table S1: Sugarcane yellow leaf virus in varieties in the primary and secondary seedcane increases at different locations and years.

Author Contributions: Conceptualization, S.S.; methodology, S.S.; validation, S.S.; writing—original draft preparation, S.S.; writing, review and editing, S.S.; planting fields and sample collection, W.R.D.; planting fields and sample collection, M.B. All authors have read and agreed to the published version of the manuscript.

Funding: This research received no external funding.

Acknowledgments: We would like to acknowledge the contributions of Miriam Baltazar, B.J. Cruz, Velton Bank, Johnny Tajeda, Wang Tajeda and Mathew Paige.

Conflicts of Interest: The authors declare no conflict of interest.

\section{References}

1. USDA-NASS. Available online: https://downloads.usda.library.cornell.edu/usda-esmis/files/k35694332/348509606/d791t8 62r/cpvl0221.pdf (accessed on 24 August 2021).

2. USDA-NASS. Available online: https://www.nass.usda.gov/Surveys/Program_Review/index.php (accessed on 24 August 2021).

3. Lalman, J.A.; Shewa, W.A.; Gallagher, J.; Ravella, S. Biofuels production from renewable feedstocks. In Quality Living through Chemurgy and Green Chemistry; Lau, P.C.K., Ed.; Springer: Berlin/Heidelberg, Germany, 2016; pp. 193-220.

4. Carvalho-Netto, O.V.; Bressiani, J.A.; Soriano, H.L.; Fiori, C.S.; Santos, J.M.; Barbosa, G.V.S.; Xavier, M.A.; Landell, M.G.A.; Pereira, G.A.G. The potential of the energy cane as the main biomass crop for the cellulosic industry. Chem. Biol. Technol. Agric. 2014, 1, 20. [CrossRef]

5. Moonan, F.; Molina, J.; Mirkov, T.E. Sugarcane yellow leaf virus: An emerging virus that has evolved by recombination between luteoviral and poleroviral ancestors. Virology 2000, 269, 156-171. [CrossRef] [PubMed]

6. D'Arcy, C.J.; Domier, L. Luteoviridae. In Virus Taxonomy. 8th Report of the International Committee on Taxonomy of Viruses; Fauquet, C.M., Mayo, M.A., Maniloff, J., Desselberger, U., Ball, L.A., Eds.; Elsevier Academic Press: New York, NY, USA, 2005; pp. 891-900.

7. Rott, P.; Kaye, C.; Naranjo, M.; Shine, J.M.; Sood, S.; Comstock, J.C.; Raid, R.N. Controlling sugarcane diseases in Florida: A challenge in constant evolution. In Proceedings of the 29th Congress of the International Society of Sugar Cane Technologists, Chiang Mai, Thailand, 5-8 December 2016; pp. 595-600.

8. ElSayed, A.I.; Boulila, M.; Komor, E.; Zhu, Y.J. Putative recombination signature and significance of deletion/insertion events in RdRp coding region of Sugarcane yellow leaf virus. Biochimie 2012, 94, 1764-1772. [CrossRef] [PubMed]

9. Filloux, D.; Fernandez, E.; Comstock, J.C.; Mollov, D.; Roumagnac, P.; Rott, P. Viral Metagenomic-Based Screening of Sugarcane from Florida Reveals Occurrence of Six Sugarcane-Infecting Viruses and High Prevalence of Sugarcane yellow leaf virus. Plant Dis. 2016, 102, 2317-2323. [CrossRef]

10. Boukari, W.; Kaye, C.; Wei, C.; Hincapie, M.; LaBorde, C.; Irey, M.; Rott, P. Field infection of virus-free sugarcane by Sugarcane yellow leaf virus and effect of yellow leaf on sugarcane grown on organic and on mineral soils in Florida. Plant Dis. 2019, 103, 2367-2373. [CrossRef]

11. Aljanabi, S.M.; Parmessur, Y.; Moutia, Y.; Saumtally, S.; Dookun, A. Further evidence of the association of a phytoplasma and a virus with yellow leaf syndrome in sugarcane. Plant Pathol. 2005, 50, 628-636. [CrossRef]

12. Chinnaraja, C.; Viswanathan, R. Variability in yellow leaf symptom expression caused by the Sugarcane yellow leaf virus and its seasonal influence in sugarcane. Phytoparasitica 2015, 43, 339-353. [CrossRef] 
13. Grisham, M.P.; Pan, Y.B.; Legendre, B.L.; Godshall, M.A.; Eggleston, G. Effect of sugarcane yellow leaf virus on sugarcane yield and juice quality. Proc. Inter. Soc. Sugar Cane Technol. 2001, 24, 434-438.

14. Comstock, J.C.; Irey, M.S.; Lockhart, B.E.L.; Wang, Z.K. Incidence of yellow leaf syndrome in CP cultivars based on polymerase chain reaction and serological techniques. Sugar Cane 1998, 4, 21-24.

15. Abu Ahmad, Y.; Rassaby, L.; Royer, M.; Borg, Z.; Braithwaite, K.S.; Mirkov, T.E.; Irey, M.S.; Perrier, X.; Smith, G.R.; Rott, P. Yellow leaf of sugarcane is caused by at least three different genotypes of sugarcane yellow leaf virus one of which predominates on the Island of Réunion. Arch. Virol. 2006, 151, 1355-1371. [CrossRef]

16. Chinnaraja, C.; Viswanathan, R.; Karuppaiah, R.; Bagyalakshmi, K.; Malathi, P.; Parameswari, B. Complete genome characterization of sugarcane yellow leaf virus from India: Evidence for RNA recombination. Eur. J. Plant Pathol. 2013, 135, 335-349. [CrossRef]

17. Gao, S.-J.; Lin, Y.-H.; Pan, Y.-B.; Damaj, M.B.; Wang, Q.-N.; Mirkov, T.E.; Chen, R.-K. Molecular characterization and phylogenetic analysis of Sugarcane yellow leaf virus isolates from China. Virus Genes 2012, 45, 340-349. [CrossRef]

18. Lu, J.J.; He, E.Q.; Bao, W.Q.; Chen, J.S.; Sun, S.R.; Gao, S.J. Comparative genomics reveals insights into genetic variability and molecular evolution among sugarcane yellow leaf virus populations. Sci. Rep. 2021, 11, 7149. [CrossRef]

19. Gonçalves, M.C.; Vega, J.; Oliveira, J.G.; Gomes, M.M.A. Sugarcane yellow leaf virus infection leads to alterations in photosynthetic efficiency and carbohydrate accumulation in sugarcane leaves. Fitopatol. Bras. 2005, 30, 10-16. [CrossRef]

20. Lehrer, A.; Yan, S.-L.; Fontaniella, B.; ElSayed, A.; Komor, E. Carbohydrate composition of sugarcane cultivars that are resistant or susceptible to sugarcane yellow leaf virus. J. Gen. Plant Pathol. 2010, 76, 62-68. [CrossRef]

21. Vega, J.; Scagliusi, S.M.M.; Ulian, E.C. Sugarcane yellow leaf disease in Brazil: Evidence of association with a luteovirus. Plant Dis. 1997, 81, 21-26. [CrossRef] [PubMed]

22. Viswanathan, R.; Chinnaraja, C.; Malathi, P.; Gomathi, R.; Rakkiyappan, P.; Neelamathi, D.; Ravichandran, V. Impact of sugarcane yellow leaf virus (SCYLV) infection on physiological efficiency and growth parameters of sugarcane under tropical climatic conditions in India. Acta Physiol. Plant. 2014, 36, 1805-1822. [CrossRef]

23. Comstock, J.C.; Miller, J.D. Yield comparisons: Disease-free tissue culture versus bud-propagated sugarcane plants and healthy versus yellow leaf infected plants. J. Am. Soc. Sugar Cane Technol. 2004, 24, 31-40.

24. Lockhart, B.E.L.; Cronje', C.P.R. Yellow leaf syndrome. In A Guide to Sugarcane Diseases; Rott, P., Bailey, R.A., Comstock, J.C., Croft, B.J., Saumtally, A.S., Eds.; CIRAD-ISSCT: Montpellier, France, 2000; pp. 291-295.

25. Scagliusi, S.M.; Lockhart, B.E.L. Transmission, characterization, and serology of a luteovirus associated with yellow leaf syndrome of sugarcane. Phytopathology 2000, 90, 120-124. [CrossRef]

26. Costet, L.; Raboin, L.-M.; Payet, M.; D'Hont, A.; Nibouche, S. A major quantitative trait allele for resistance to the sugarcane yellow leaf virus (Luteoviridae). Plant Breed. 2012, 131, 637-640. [CrossRef]

27. Islam, M.S.; Yang, X.; Sood, S.; Comstock, J.C.; Wang, J. Molecular characterization of genetic basis of sugarcane yellow leaf virus (SCYLV) resistance in Saccharum spp. hybrid. Plant Breed. 2018, 137, 598-604. [CrossRef]

28. Debibakas, S.; Rocher, S.; Garsmeur, O.; Toubi, L.; Roques, D.; D’Hont, A.; Hoarau, J.Y.; Daugrois, J.H. Prospecting sugarcane resistance to Sugarcane yellow leaf virus by genome-wide association. Theor. Appl. Genet. 2014, 127, 1719-1732. [CrossRef]

29. Gouy, M.; Rousselle, Y.; Chane, A.T.; Anglade, A.; Royaert, S.; Nibouche, S.; Costet, L. Genome wide association mapping of agro-morphological and disease resistance traits in sugarcane. Euphytica 2015, 202, 269-284. [CrossRef]

30. Pimenta, R.J.G.; Aono, A.H.; Burbano, R.C.V.; Coutinho, A.L.; da Silva, C.C.; dos Anjos, I.A.; Perecin, D.; Landell, M.G.A.; Gonçalves, M.C.; Pinto, L.R.; et al. Genome-wide approaches for the identification of markers and genes associated with sugarcane yellow leaf virus resistance. Sci. Rep. 2021, 11, 15730. [CrossRef] [PubMed]

31. Francki, R.I.B.; Milne, R.G.; Hatta, T. Atlas of Plant Viruses; CRC Press: Boca Raton, FL, USA, 1985; Volume 1, pp. $137-141$.

32. Rassaby, L.; Girard, J.-C.; Lemaire, O.; Costet, L.; Irey, M.; Kodja, H.; Lockhart, B.E.L.; Rott, P. Spread of Sugarcane yellow leaf virus in sugarcane plants and fields on the island of Réunion. Plant Pathol. 2004, 53, 117-125. [CrossRef]

33. Schenck, S.; Lehrer, A.T. Factors affecting the transmission of Sugarcane yellow leaf virus. Plant Dis. 2000, 84, 1085-1088. [CrossRef]

34. Boukari, W.; Wei, C.; Tang, L.; Hincapie, M.; Naranjo, M.; Nuessly, G.; Beuzelin, J.; Sood, S.; Rott, P. Lack of transmission of Sugarcane yellow leaf virus in Florida from Columbus grass and sugarcane to sugarcane with aphids or mites. PLoS ONE 2020, 15, e0230066. [CrossRef]

35. Lehrer, A.T.; Kusalwong, A.; Komor, E. High incidence of Sugarcane yellow leaf virus (SCYLV) in sugar plantations and germplasm collections in Thailand. Australas. Plant Dis. Notes 2008, 3, 89-92. [CrossRef]

36. Zhou, G.H.; Li, J.G.; Xu, D.L.; Shen, W.K.; Deng, H.H. Occurrence of Sugarcane yellow leaf virus in South China and its transmission by the sugarcane colonizing aphid, Ceratovacuna lanigera. Sci. Agric. Sin. 2006, 39, 2023-2027.

37. Chatenet, M.; Delage, C.; Ripolles, M.; Irey, M.; Lockhart, B.E.L.; Rott, P. Detection of Sugarcane yellow leaf virus in quarantine and production of virus-free sugarcane by apical meristem culture. Plant Dis. 2001, 85, 1177-1180. [CrossRef]

38. Fitch, M.M.M.; Lehrer, A.T.; Komor, E.; Moore, P.H. Elimination of Sugarcane yellow leaf virus from infected sugarcane plants by meristem tip culture visualized by tissue blot immunoassay. Plant Pathol. 2001, 50, 676-680. [CrossRef]

39. Parmessur, Y.; Aljanabi, S.; Saumtally, S.; Dookun-Saumtally, A. Sugarcane yellow leaf virus and sugarcane yellows phytoplasma: Elimination by tissue culture. Plant Pathol. 2002, 51, 561-566. [CrossRef] 
40. Chinnaraja, C.; Viswanathan, R.; Sathyabhama, M.; Parameswari, B.; Bagyalakshmi, K.; Malathi, P.; Neelamathi, D. Quantification of Sugarcane yellow leaf virus in in vitro plantlets and asymptomatic plants of sugarcane by RT-qPCR. Curr. Sci. 2014, 106, 729-734.

41. Zhao, D.; Comstock, J.C.; Glaz, B.; Edmé, S.J.; Glynn, N.C.; Del Blanco, I.A.; Gilbert, R.A.; Davidson, R.W.; Chen, C.Y. Vigor rating and Brix for first clonal selection stage of the Canal Point sugarcane cultivar development program. J. Crop Improv. 2012, 26, 60-75. [CrossRef]

42. Tai, P.Y.P.; Miller, J.D. Family performance at early stages of selection and frequency of superior clones from crosses among Canal Point cultivars of sugarcane. J. Am. Soc. Sugar Cane Technol. 1989, 9, 62-70.

43. Schenck, S.; Hu, J.S.; Lockhart, B.E.L. Use of a tissue blot immunoassay to determine the distribution of sugarcane yellow leaf virus in Hawaii. Sugar Cane 1997, 4, 5-8.

44. Comstock, J.C.; Miller, J.D. Incidence and spread of Sugarcane yellow leaf virus in sugarcane clones in the CP-cultivar development program at Canal Point. J. Am. Soc. Sugar Cane Technol. 2003, 23, 71-78.

45. Lehrer, A.T.; Komor, E. Symptom expression of yellow leaf disease in sugarcane cultivars with different degrees of infection by Sugarcane yellow leaf virus. Plant Pathol. 2008, 57, 178-189. [CrossRef]

46. Guinet-Brial, I.; Girard, J.C.; Roumagnac, P.; Daugrois, J.H.; Fernandez, E.; Rott, P. Visacane, an innovative quarantine tool for the exchange of pest and disease-free sugarcane germplasm. In Proceedings of the 28th International Society of Sugar Cane Technologists Congress, Sao Paolo, Brazil, 24-27 June 2013; pp. 890-896.

47. Daugrois, J.H.; Jean-Baptiste, I.; Lockhart, B.E.L.; Irey, M.; Chatenet, M.; Rott, P. First report of sugarcane yellow leaf virus in French West Indies. Plant Dis. 1999, 83, 588. [CrossRef]

48. Komor, E.; ElSayed, A.; Lehrer, A.T. Sugarcane yellow leaf virus introduction and spread in Hawaiian sugarcane industry: Retrospective epidemiological study of an unnoticed, mostly asymptomatic plant disease. Eur. J. Plant Pathol. 2010, 127, 207-217. [CrossRef]

49. Chinnaraja, C.; Viswanathan, R. Quantification of sugarcane yellow leaf virus in sugarcane following transmission through aphid vector, Melanaphis sacchari. Virus Dis. 2015, 26, 237-242. [CrossRef] [PubMed]

50. Lehrer, A.; Schenck, S.; Yan, S.; Komor, E. Movement of aphid-transmitted Sugarcane yellow leaf virus (ScYLV) within and between sugarcane plants. Plant Pathol. 2006, 56, 711-717. [CrossRef] 